Corresponding Author:

Dima Saber, Birmingham City University, School of Media, Parkside Building, Cardigan Street, Birmingham, B4 7BD.

Email: dima.saber@bcu.ac.uk

\title{
'This is our Call of Duty': Hegemony, History and Resistant Videogames in the Middle East
}

\section{Dima Saber}

Birmingham City University, UK

\section{Nick Webber}

Birmingham City University, UK

\begin{abstract}
In recent years, non-state actors in the Middle East have engaged a new generation of activists through a variety of media strategies. Notable amongst these have been a series of videogame interventions, which have appropriated Western game products to convey specific political and religious messages through the inversion or complication of the roles of hero and enemy. This article explores a selection of such media, produced by or in support of two prominent non-state groups, Hezbollah and Islamic State (IS).

The article takes a discourse theoretical approach to examine the ideologies presented in these media, and reflects on the ways in which these game artefacts engage with, and reject, Western narratives of history and of US pre-eminence. It concludes that, while these game interventions challenge existing hegemonic (re)presentations of the Middle East and the 'War on Terror', they remove or reduce agency to the extent that those who engage with them can only witness these challenges, rather than instigate their own. We view this lack of agency as support for Mouffe's (2005) proposition that more often than not the result of counter-hegemonic resistance is to maintain and reproduce the hegemonic order, though we acknowledge that this is not inevitable, as hegemony can always be challenged (Mouffe, in Carpentier and Cammaerts, 2006).
\end{abstract}

\section{Keywords}

War on Terror, Islamic State, Hezbollah, videogame, history, hegemony, discourse theoretical analysis

\section{Introduction}


In recent years, non-state actors in the Middle East have engaged a new generation of activists through a variety of media strategies. Notable amongst these have been a series of videogame interventions, which have appropriated Western game products to convey political and religious messages through the inversion or complication of the roles of hero and enemy. These 'resistant' videogames and associated media offer a space to think through the nature of hegemonic and counter-hegemonic representations of the activities of groups which, in the West at least, are typically identified as terrorist or insurgent, and fall within the purview of the ongoing 'War on Terror', a contemporary conflict but one with a fifteen year history.

In this article, we explore a selection of videogame interventions produced in support of two of the more prominent 'terrorist' groups, Hezbollah and Islamic State (IS). These include, on the part of Hezbollah, the Al Quwwa el-Khassa ('Special Force', $S F$ ) video games, produced by the Central Internet Bureau of Hezbollah in 2002, after the withdrawal of the Israeli army from South Lebanon (SF 1), and in 2007, in the aftermaths of the July 2006 war between Israel and the Hezbollah ( $S F$ 2). On the part of IS, we look at the video mashup Salil el-Sawarem ('Clash of Blades'), produced using Grand Theft Auto V (GTA), and at a machinima series produced using a modified version of ArmA 3. ${ }^{1}$ These game artefacts work across the range of 'forms of indigenous militarisation' in protest games identified by Nick Robinson - existing game spaces used as sites of political protest (GTA), modifications to existing games to create spaces for social protest (ArmA 3), and games specifically designed to challenge the dominant social order (SF 1 and 2) (Robinson, 2012: 505, 513).

We take a discourse theoretical approach to examining the ideologies at play in these media, and consider how the intersection of videogames and modern information and communication technologies affords not only the production and circulation of 'dissident' content, but also the effective conveyance of meaningful political messages. Our analysis is contextualised in the representation of political Islam in mainstream media, and reflects on the ways in which these game artefacts engage with, and reject, Western narratives of history and of US pre-eminence. Our discussions and conclusions contribute to debates around the politics of militarised entertainment, around the relationships of media and resistance, and around the historical potential of videogames.

\section{The Middle East as 'the favourite ground' of the US perpetual 'War on Terror'}

A possible point of departure for our exploration of Hezbollah and IS videogames is the deeprooted relationship between games and militarism. There is broad consensus in the literature of the last two decades on the longstanding connection between videogames, specifically those produced in the United States, and what has been labelled the 'military-entertainment complex' (Huntmann and Payne 2010; Bogost 2007 and 2008; Der Derian 2009; Robinson 2012; Šisler 2008, among others). Often referred to as a post-Cold war phenomenon, the 'militaryentertainment complex' attests to the blurred frontiers between entertainment as a media genre, and the ever-expanding military power of the United States (Huntemann and Payne, 2010: 6). In the same way, scholars see this blurring as the natural result of the 'development in military 
ethos towards a net-centric warfare' where computer technology and military supremacy on battlefield have become increasingly intertwined (Der Derian, 2009: 241-242).

Nonetheless, these connections between videogames and contemporary conflicts - most notably the post-9/11 US 'War on Terror' - have pushed scholars from across the Arts, Humanities and Social Sciences to call for more serious studies of videogames (Robinson, 2012). They also highlight the need to mobilise a cross-disciplinary methodological matrix from Media and Cultural Studies, Post-Colonial Studies, Sociology, History and Political Science to explore the complex relationships between the game space that military games produce, the narratives they construct and the militarisation of politics and society more broadly. Through using the discourse theoretical approach as a methodological framework for the analysis of Hezbollah and IS videogame productions, this article responds to the call to incorporate theoretical tools associated with Cultural Studies in the analysis of games (Höglund, 2008).

Unsurprisingly, the Middle East has been, since the end of the cold war, the focus and epicentre of this US 'military-entertainment complex', to an extent that it has been referred to as the 'favourite virtual battleground' of the perpetual US battles against terrorism (Šisler, 2008: 208). As such, as Šisler's study demonstrates, most military games produced in the United States since the 1990s, and in the aftermath of the Afghanistan and Iraq wars, take place in an imagined Middle East. These games have, for the most part, inherited the West's mainstream orientalising systems of political identification (Said, 1978 and 1997); the representations of Arab and Muslim inhabitants of this virtual Middle East are generally based on a series of dichotomies between a civilised, modern, democratic and peace-loving (Western) self, and an uncivilised, archaic, totalitarian and violent (Arab) other (Hafez, 2000; Shaheen, 2000; Karim, 2006; Šisler, 2008).

These overgeneralising depictions of Arabs in US games have been addressed - and largely criticised - by a number of scholars, many of whom are referenced at the end of this article. Two main contributions from this vast body of literature are particularly useful for the argument we are attempting to make in this piece: on the one hand, the concept of 'neo-Orientalism'; and on the other, the depiction of the Middle-East as the site of a 'permanent state of war', ${ }^{2}$ both presented in Höglund's (2008) article 'Electronic Empire: Orientalism revisited in the military shooter'. Building on Edward Said's Orientalism, Höglund introduces the concept of neoOrientalism, which he defines as a discourse within military electronic entertainment 'characterized by the construction of the Middle East as a frontier zone where a perpetual war between US interests and Islamic terrorism is enacted' (2008). This creates a framework within which the Middle East remains a space where the US can endlessly fight its (necessary) 'War on Terror'. It is in the interest of the United States that this war never ends, in the same way, Höglund writes, that in Orwell's 1984, it is in the interest of governments that certain wars never stop, because 'not only does a perpetual war fuel a nation's (war) industry indefinitely, [but] it also allows the beleaguered nation to believe that the hostile (but never finally defined) Other is being perpetually contained' (2008: n.p.).

But who is/are the Other(s) that the US is fighting in its (real) 'War on Terror', and through its war games, often presented to us as (realistic) ${ }^{3}$ depictions of this war? Indeed, has much changed in the ways political Islam is depicted in today's mainstream narratives, nearly four decades after the publication of Edward Said's influential book Orientalism? We propose, as a possible 
response to this question, that we imagine Otherness as a single elastic frame; while there may be several ways one could be an other, all disparate expressions of Otherness need to fit into this one, single frame. The elastic borders of the frame would stretch to include new others, more others - as the United States and its Western allies wage new wars, more wars. The frame adapts itself to new military realities, but does not really change. In other words, the same Otherness which 'contained' Hezbollah videogames and their visual media productions in the early 2000s has now stretched to include a new other: Islamic State and its new media narratives. Both are part of the same frame of Otherness, even though they fight on opposing sides in the Syrian war. In that sense, we can say that little has changed, as the Western hegemonic gaze still persists in compressing all expressions of political Islam into a single 'terrorist' frame; as GW Bush famously remarked in his address to the US Congress on September 20, 2001: 'either you are with us or you are with the terrorists'. Here, then, we must attempt to move beyond such binary depictions of war.

\section{Making games that make statements: ideology, hegemony, history and the 'persuasive power' of games}

Before we move on, however, some definitions are in order. Following Šisler's definition of representation as 'the construction of meaning through symbols and images' (2008: 203), we embrace Galloway's (2004) suggestion that traditional debates on representation should include visual productions and videogames. We also acknowledge Bogost's (2007) argument for the unique 'persuasive powers' of some (political) videogames: 'they open a new domain for persuasion through rule-based representations and interactions, different than the spoken word, writing, images and moving pictures' (2007: ix).

Following Louis Althusser's Ideological State Apparatuses (Althusser, 2001: 96), we approach ideology as the set of ideals, values, doctrines, principles and symbols that defines a social order. In that sense, we emphasize the role ideology plays in the construction of the image of the 'self' and the 'other', especially in contexts of societal and political struggles for representation. We also acknowledge, within the framework of Laclau and Mouffe's (1985) discourse theory, the Gramscian origins of the notion of hegemony, and define it as the concept that underpins and reflects mechanisms of discursive struggles. In this context, Carpentier suggests a useful approach to understanding the role of hegemony in situations of conflict: 'In the event of war the articulation of hegemony becomes relevant as the warring parties not only try to physically destroy the enemy, but also attempt to hegemonize their "own" discourses on the enemy and on the self' (2008: 30-31).

By extending these definitions to videogames, we argue that war games operate with similar ideological mappings; on the one hand, they are vehicles that convey and disseminate the dominant ideologies of the hegemonising powers, and by doing so reinforce pre-conceived cultural stereotypes upon the self and upon the other. On the other hand, the rise of new information and communication technologies and the democratisation of image production and distribution has made it possible for counter-hegemonic forces to produce their own games and narratives of dissent, thus challenging the perspectives of the 'military-entertainment complex' 
by offering alternatives to the Western-led militarisation of society. Chantal Mouffe explains that every hegemonic order is susceptible to be challenged by counter-hegemonic practices, 'i.e. practices which will attempt to disarticulate the existing order so as to install other forms of hegemony' (2005: 18). We will return to the notion of new forms of hegemony later, but for the time being, it is precisely in these negotiated spaces between hegemonic and counter-hegemonic struggles for representation that our analysis of Hezbollah and IS videogame productions finds its main anchoring points.

In their analysis of the representation of otherness in US First-Person Shooter (FPS) games, Intizidis and Prevedourakis explain that videogames combine multiple modes of representation audiovisual, textual, and digital genres and discourses - 'through which both the self and the other are constantly imagined, constructed, and articulated' (2008: 209). These discourses are essentially political 'because they ascribe meaning to the gamer's actions and to the overall causal environment' (2008: 216). They also accompany the formation of national identities; a collective 'we' opposed to a distinct 'them' (2008: 210). Building on Fairclough's (1997) approach to discourse as a medium for the social construction of meaning, we suggest approaching videogames as discourses, ${ }^{4}$ with discourses being structures in which meaning is constantly negotiated and constructed (Laclau, 1988: 254). Within these structures, it becomes possible for videogames 'to make arguments, to persuade and to express ideas' (Bogost, 2008: 137). Produced within contexts where there are constant struggles over societal and political meanings, games can then contribute to these struggles in two ways; 'through the messages they contain, and through their dynamics of play' (Robinson, 2012: 507). In this context, Robinson sees in Bogost's 'procedural rhetoric' - 'a technique for making arguments with computational systems and for unpacking computational arguments others have created' (Bogost, 2007:3) - a useful entry point to describe ways in which videogames have the potential to challenge dominant hegemonies and ideologies.

As we will demonstrate in more detail below, one specific site of ideological conflict in which we can see these game materials offer an antagonistic discourse is the space of history. In the case of the Special Force games, for example, there is a deliberate and explicit reimagining of a series of past events. In the far more recent ArmA 3 machinima, the events referenced are both contemporary and historic - the present conflict in Iraq and Syria evoked by the 'IS brand', and the conceptions of the Middle East as a site of endless war discussed above. Thus earlier interventions like Special Force 2 (concerned with the 2006 July War in Lebanon) reject or complicate narratives of what is seen by Westerners as a historic war, now ended; more recent productions, predominantly supporting IS, reject or complicate the growing history of the War on Terror by addressing conflicts which are still taking place. These perspectives thus present a case for a particular kind of historicisation of this warfare within the framing of the "endless war in the Middle East', rejecting this idea in favour of an 'endless war with the West'.

These rejections and complications are laid out in a variety of forms across the materials we examine. We accept here Keith Jenkins' (2003: 31-2) proposition that history is a discourse about the past created by 'present-minded workers' and, as a consequence, we accept the arguments of a number of writers who indicate that the experience of the past presented by and through videogames is a legitimate form of history (see, for example, Kapell and Elliott, 2013). 
Important is the sense of tension which exists in games which engage with the past, between 'simulation' and 'representation' (Peterson, Miller and Fedorko, 2013: 35-6), specified by Gonzalo Frasca (2003) as between the simulation mode of games, and the representational narrative mode of traditional media. The implications of this distinction hold even greater significance when considered in terms of history, something especially true in light of the contributions of writers such as Hayden White (1990), who have explored in detail the relationship between narrative and historical representation, and, indeed, historical truth. Given that many (Western) expectations of historical work remain grounded in notions of objectivity, causation and codification running back to the Greek historian Thucydides, the 'rigorous standards' of true historical representation are rarely met by video games (Peterson, Miller and Fedorko, 2013: 35-6). Consequently, it is more accurate to consider the majority of historical games as simulations: they do engage with the past, but 'at almost no point do these games feature a factually correct past', with accuracy often sacrificed in favour of, for example, a good gameplay experience (Kapell and Elliott, 2013: 358).

\section{Antagonistic discourses on the enemy and the self through Hezbollah and IS videogame productions}

With these principles established, we move on to investigate the potential of these videogame interventions to offer antagonistic discourses. While a considerable body of literature has addressed the ways in which these games challenge the Western-led militarisation of society through methods drawn from semiotics and textual analysis (see Šisler, 2008; 2009; Roumani, 2006; Robinson, 2012; Höglund, 2008), we suggest looking at these productions from a different angle. We will first analyse depictions of the self within Hezbollah and IS productions, and then focus on the many differences between the two groups' 'dissident' narratives. This will allow us to counter the Western generalising gaze, which, as we mentioned earlier in the article, insists on compressing different expressions of political Islam into a single 'terrorist' frame.

Hezbollah was established in 1982 as a response to Israel's invasion of Beirut, and within only a few years was recognized as a 'legitimate resistance movement' against the Israeli occupation of Southern Lebanon (Palmer Harik, 2005). By participating in the 1992 elections, Hezbollah established itself as a political party, extending its popular base beyond the Shiite communities to win support and recognition both nationally and regionally. Despite the countless controversies it has since sparked around its legitimacy and politics, Hezbollah has undoubtedly set a precedent in Lebanon and the Arab region in terms of its various media productions, including its music videos, filmed military operations (Houri and Saber, 2010), and videogames.

These politics are forcefully conveyed in these media forms. Special Force 2, for example, opens with 'verbal rhetoric' (Bogost, 2007: 104), an Arabic text ${ }^{5}$ which contextualises the action, casting Israel as the 'enemy' whom the gamer is invited to 'resist'. So here we see the subversion of a familiar game environment to create a new narrative where there is only space for a new, glorified 'self'. 


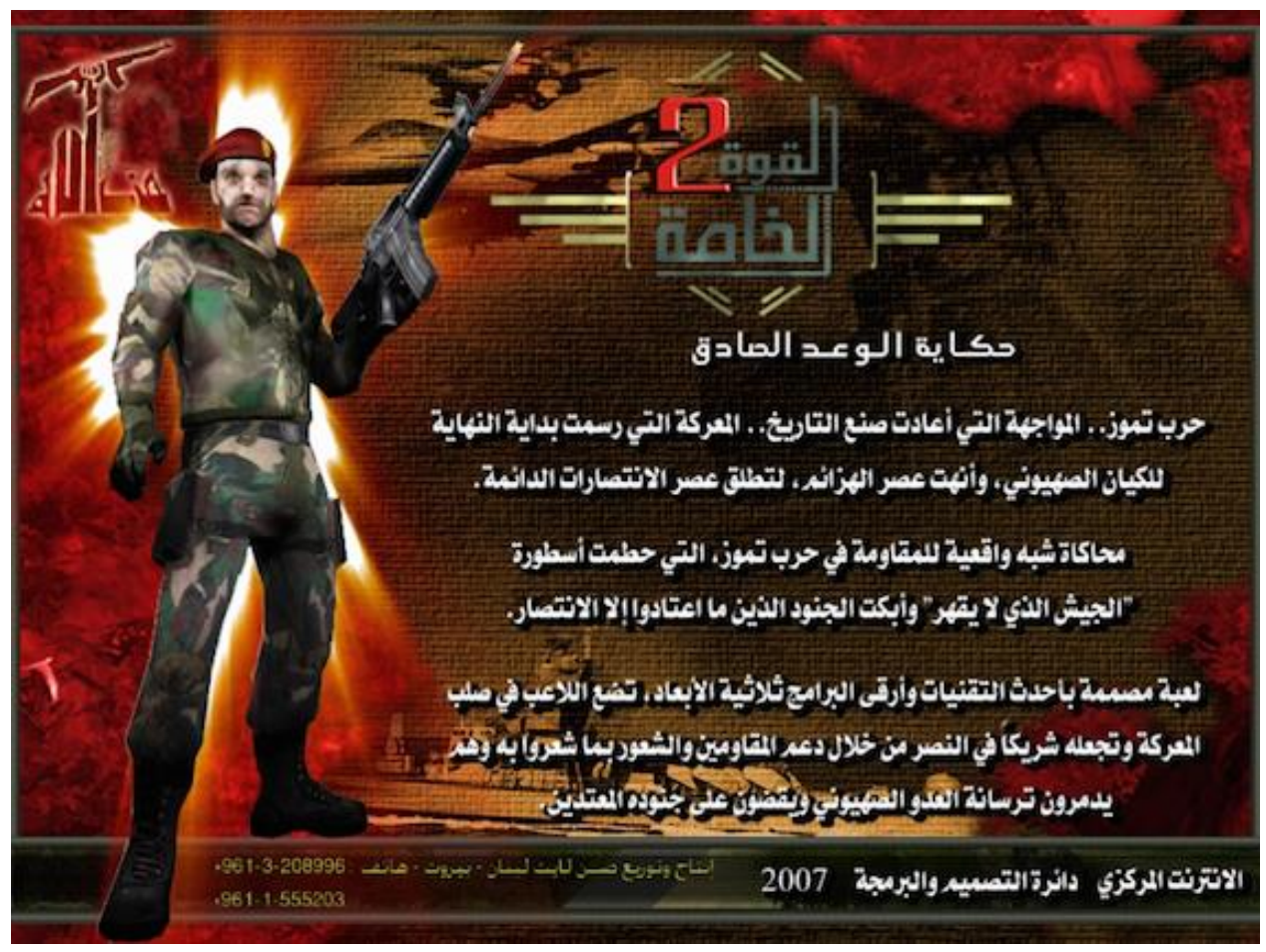

Figure 1: Special Force 2 opening screen

(Author-captured screenshot of gameplay)

Videogames are based on a series of discursive framings, 'as they (visually, textually and sonically) construct meanings, through narratives that combine filmic, literary, and textual modes of representation' (Intizidis and Prevedourakis, 2008: 210). Central to these mediated narratives in US war games, and more particularly in First-Person Shooter (FPS) games, is the American GI. Typically, he is presented 'as a noble hero, embracing the ideals of loyalty, honour, sacrifice and above all patriotism' (Penney, 2010: 190). This American 'hero' often has allies; from different places, with different origins, and with different skills on the virtual battlefield. The enemy, on the other hand, is 'vague, homogenous, massive and rigid' (Intizidis and Prevedourakis, 2008: 215). More often than not in recent games, the enemy is an Arab, from the Middle East; he is the 'villain' that the GI is meant to fight against. Bogost (2007) explains that one of the most curious 'procedural rhetorics' of US war games like America's Army is that, despite this being a multiplayer game, everyone always takes on the role of US Army soldiers. 'No one ever plays a villain fighting the US, both teams play the same mission with one assaulting and the other defending, but [they] both believe themselves to be the "good guys"" (Bogost, 2007: 75). Thus, by substituting the American GI with a thick-bearded man who looks and speaks Arabic $(S F)$, and by extending the range of fighters' roles that players can perform to include Iraqi and Kurdish army men, and camouflaged IS fighters (ArmA 3 mod), these videogame productions create new sites of protest, wherein gamers can identify with a different point of view from that of the American GI. This, one could argue, is a characteristic which Hezbollah and IS videogame productions share. 


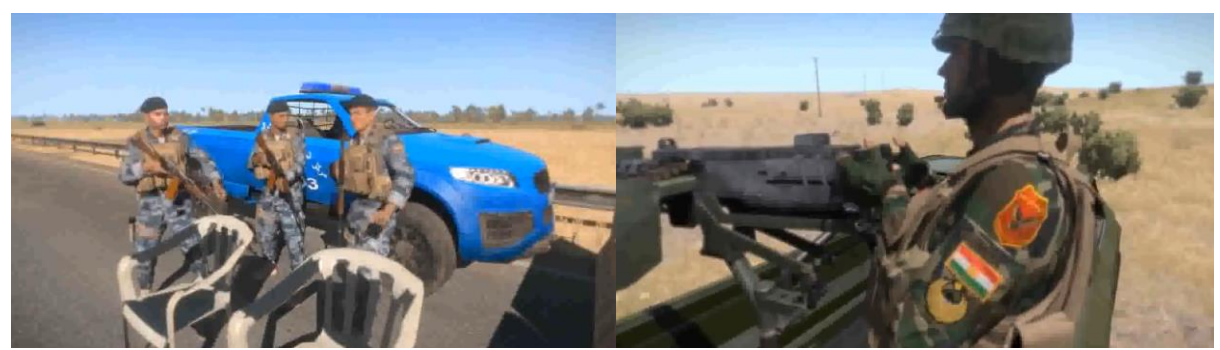

Figure 2: An Iraqi army outpost and a Kurdish fighter from the Peshmerga army (ArmA 3 mod) (Author-captured screenshot of gameplay)

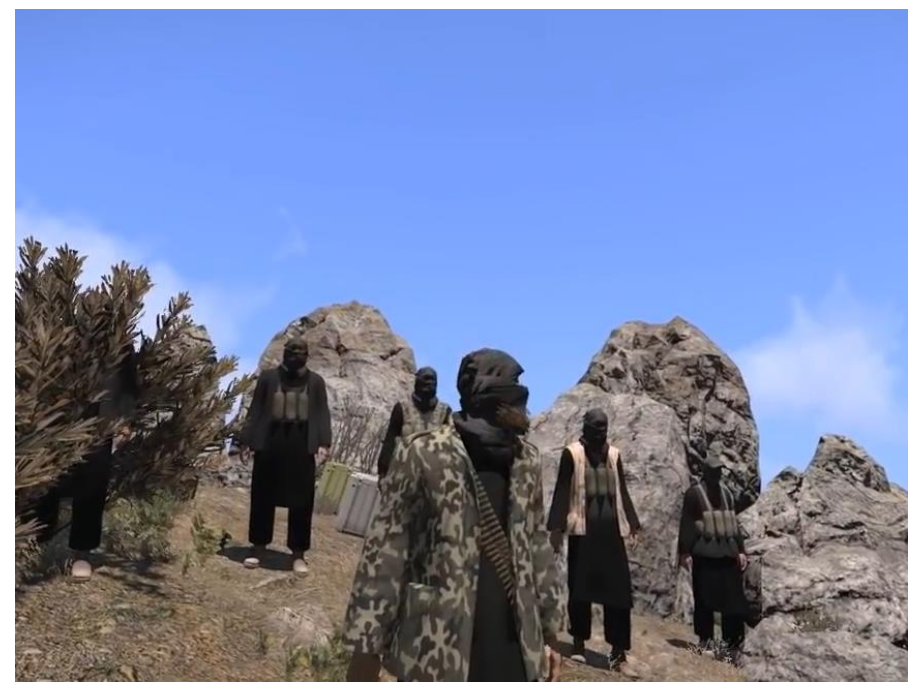

Figure 3: IS fighters (ArmA 3 mod)

(Author-captured screenshot of gameplay)

In these new 'possibility spaces' (Bogost, 2008: 137), ${ }^{6}$ the classic good-versus-evil matrix is preserved, only the roles have now been switched; the Middle Eastern other has become the heroic self, and the Western self the other. Indeed, the now-othered American self is almost absent from the dissident histories these videogames produce. Both the game space and the narratives it constructs are entirely dedicated to the celebration of the now-victorious MiddleEastern self. Yet the possibilities for their players or audiences remain limited. While the Special Force narratives may differ in perspective and outcome from those in a typical Western game of this kind, they are fixed narratives and the player is not afforded any form of narrative exploration; to successfully complete the game is to experience the narrative exactly as intended by its authors. The IS interventions are yet more restrictive; they are not games in themselves, and their possibilities are thus vested in an implied game, used to create media to be explored by passive viewers rather than active players.

\section{On the distinctions between Hezbollah and IS videogame interventions}

In his description of the virtual Middle East as depicted in games funded by the militaryentertainment complex, Höglund (2008) explains that US war games render an 'ideological 
space that really has very little to do with the reality in the Middle East, but which makes perfect sense within the wider discursive formation of the War on Terror launched by Bush after 9/11'. While in the 'real' Middle East, IS and Hezbollah fight on opposing sides of the Syrian war, 'realistic' Western mainstream narrations insist on depicting IS and the Hezbollah as two aspects of one 'utterly evil enemy' (Laclau, 1977) - of one 'terrorist' other. We identify below three differences between Hezbollah and IS videogame productions; for the sake of brevity, we limit our analysis to design, authorship and audience.

\section{Design}

While IS media productions have completely adopted Western aesthetics of visual communication, and have incorporated all the affordances of new information and communication technologies, Special Force and other Hezbollah media productions have preserved a guerrilla-like aesthetic. One metaphor that would work well to describe Hezbollah media productions from the early 1990s to the present day is that of the AK-47 rifle. While the party was a true pioneer in Lebanon and the broader Arab region in the use of media and video innovations, it has always resorted to accessible and easily handled technologies that are metaphorically 'the Kalashnikov of image production' (Houri and Saber, 2010: 73-74). In other words, the cheaper and poorer-quality video camera always seemed adequate for Hezbollah's military actions and media representations, much as the simple, lightweight and inexpensive Kalashnikov has long been associated with guerrilla warfare around the world.

In that sense, while IS videogame productions deploy the English language (e.g. Salil elSawarem's opening screen reads 'Your games which are producing from you, we do the same actions in the battlefields ') and have fully adopted Western strategies of visual representation, Special Force's design remained basic. The image quality is poor and grainy, and the game itself full of bugs, attesting to the party's preference for small-scale media productions and alternative means of broadcasting as a way to subvert and defy the imbalance that characterizes the global media landscape (Houri and Saber, 2010: 74). Significantly, however, it is Hezbollah who have created their own video games, and not IS. Special Force 1 and 2 are complete, playable games; IS employ Western video games and their aesthetics to produce visual media, but not playable media. There is not even clear evidence that the modification to ArmA 3, used as the basis of the machinima series to which we refer, was produced by IS, only that it was used by them.

\section{Authorship}

While, as described in the introduction, the Special Force games were produced by the Central Internet Bureau of Hezbollah, IS videogame productions have unknown authors and are, for the most part, the result of the 'good will' and personal initiatives taken by individuals around the world; some are IS supporters, and some are not. This reflects the globalised nature of IS, as opposed to the local and small-scale nature of the Lebanese Hezbollah. While 'headquartered' in Raqqa, IS aims to expand its control beyond Syria, Iraq and the Arab region, and as a result its media productions use a completely different language from Hezbollah to address a wider, global audience. This brings us to our third and probably most significant point.

\section{Audience}


According to the Central Internet Bureau, Special Force was developed to counter US-made games which 'enfold humiliation to many of [the] Islamic and Arab countries, where battles are running in Arab countries, [where] the dead are Arab soldiers, whereas the hero who kills them is - the player himself - an American' (cited in Šisler, 2008: 211). Therefore, the audience for games such as Special Force is mainly 'Arab gamers', as the head of the Syrian game company Afkar Media puts it (cited in Roumani, 2006). Consequently, we would disagree with Robinson's view that such games have not 'realised their persuasive potential' if their address to Western audiences has been limited (2012: 519); we would instead contend that these games were never intended to engage a Western audience. Unlike IS videogame productions which are designed for promotion and for recruitment purposes, and target both Arab and Western audiences, Hezbollah videogames were developed for a local, Arab and Arabic-speaking audience, making them substantially different from the IS productions we discuss.

As noted above, all of these videogame productions make - directly or indirectly - a bold claim: to (re)write history. In order, therefore, to situate our analysis of these artefacts within wider discussions on the legitimacy on the US 'War on Terror', we now turn to history as a specific site of negotiation of hegemonic and 'resistant' ideological narratives.

\section{Alternative or counterfactual history}

The media under analysis in this article address history in three principal ways. In the first case, this is through a storytelling form which resists established histories through a counterfactual representational narrative, in which known events are reordered or reimagined, and dialogue and other media resources selectively deployed to provide support for the story. This is, for example, the approach of Special Force 2, in which the events of the July War conclude with Hezbollah's victory, a presentation supported throughout with carefully selected contemporary media material. Of the three approaches, this is the most direct and explicit address to existing hegemonic history; in clearly framing an ideological view of the past and, consequently, an imagined 'better present', it is also the most explicit rejection of that hegemony.

In contrast, the second mode of address engages in a relationship with Western hegemonic discourse which is more in the nature of rhetoric rather than challenge. Here, Western notions of history are called upon to frame non-hegemonic interpretations, through an analogy which subjects its audience to an unpleasant shift in perspective, as the positions of Western hero and Middle Eastern enemy are reversed. This mode is demonstrated through a poster circulated online, entitled 'This is our Call of Duty'. (Although it would be impossible, as discussed above, to confidently establish authorship of this poster, the IS flag is clearly identifiable in the top right corner of the image, with the words Rayat al-Tawheed, the 'Banner' or 'Black Flag' of Tawheed, a sign of unity in the Muslim 'Ummah' claimed by IS in their communications). 


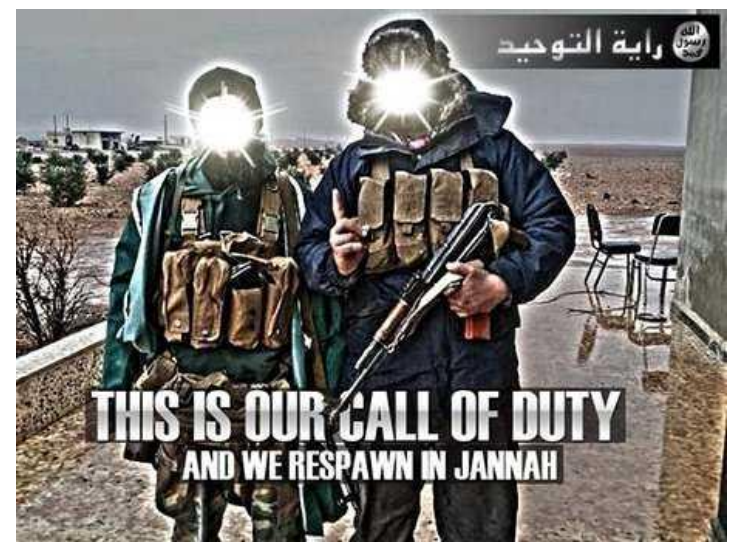

Figure 4: IS Call of Duty poster published online

(Author-captured screenshot of poster)

'This', we understand, is the 'War on Terror'. The Call of Duty franchise frames itself firmly in terms of major threats to the West/the US: the original games focused on World War 2, with subsequent releases addressing the Cold War and war in the Middle East. Here, however, 'jihad' and 'martyrdom' have replaced the original American black-ops and 'heroes'. As part of a selection of products responding to what some commentators have dubbed BrandWW2 (Bullinger and Salvati, 2011), the game presents the player as a heroic figure 'within a grand historical and nationalist narrative' (Gish, 2010: 169) in what one commentator has called 'a clear cut "good vs. evil" scenario' (Salvati and Bullinger, 2013: 154). The rhetorical action of the IS poster reverses this position, contesting this presentation and thus the 'goodness' of the 'War on Terror'.

The final form of historical address is expressed through the sense of engagement offered by the media experience itself, either through playing games such as Special Force, playing or watching the ArmA 3 mod, or watching the video production based on GTA V. Games like these, in the FPS genre, do much of their communicative work through situation: as we understand from Call of Duty, for example, games like Special Force render the player as a 'historically situated agent' (Kapell and Elliott, 2013: 10), present in a 'historically charged space' (Reisner, 2013: 248). The player is surrounded by historical context, which goes beyond the level of narrative to provide a consistent and implicit sense of a past. This 'recognisable' history is the visual rhetoric which also gives force to the video and machinima; the desert context and dress of the participants in the GTA video, for example, moves us beyond the imaginary California of the original game and into the heart of the 'War on Terror', through a discourse imprinted upon our minds throughout the war's history. 


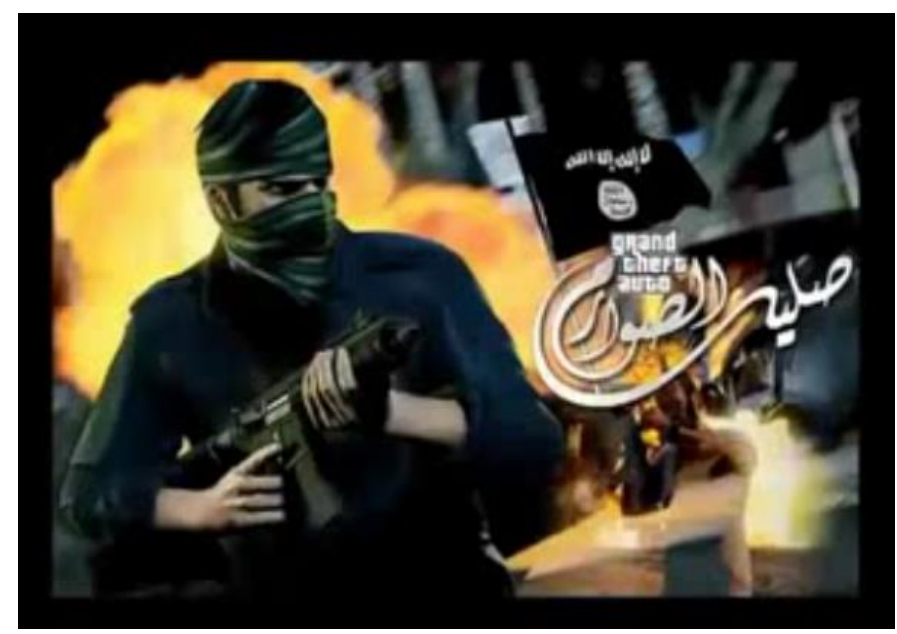

Figure 5: IS adaptation of GTA V in Salil el-Sawarem's trailer

(Author-captured screenshot of trailer)

In their presentations and engagements with the past, then, we argue that neither the Hezbollah nor the IS game artefacts will represent an 'objective' truth. They do not set out to be historical in the traditional historian's sense; rather, they attempt to provide a form of what we might call referential experience: history brought to mind in a number of different ways, more or less directly depending on the artefact under analysis. And in any case, as we have already indicated, these games offer 'resistant perspectives' on the past.

There is a growing body of work on the importance of alternative or 'counterfactual' histories in games, and their reflection of the poststructuralist turn in historical work more broadly (e.g. Uricchio, 2005; Gish, 2010; Apperley, 2013). While the exploration of what 'might-have-been' fell on the wrong side of EH Carr's division between a historical school of thought and an unhistorical school of emotion (Carr, 1964: 96-8), scholars such as Tom Apperley (2013) reject this view, seeing counterfactual history as a legitimate form of historical speculation which offers ways of critically engaging with history, and challenges the authority of hegemonic and linear histories, promoting a sense of a past which is plural and contingent. In principal, in offering the space for producing such alternatives, historical games 'subvert the project of consolidation and certainty associated with the former brand of history' (Uricchio, 2005: 333).

This in turn prompts a reflection on the idea of authenticity. Some recent work has attempted to create distance between the traditional historical use of the term, as synonymous with the accurate, and its employment in terms of historical games (and, indeed, other media presentations of history). Salvati and Bullinger have proposed the term 'selective authenticity' to describe the 'narrative license, in which an interactive experience of the past blends historical representation with generic conventions and audience expectations, all within a reductive frame'; in their case that of World War 2 (Salvati and Bullinger, 2013: 154). Kapell and Elliott favour deploying authenticity to refer not to an accurate description of a given period, but instead to 'what audiences think the period looked like' (Kapell and Elliott, 2013: 361). Yet an experiential reading of authenticity can provide a further perspective, employing the term on a more broadly cultural rather than historical basis; a sense of 'being-thereness', of bearing witness (Reisner, 
2013: 250) or, as one of us has argued elsewhere, a sense of realness deriving from that presence, from that witnessing (Carter et al., 2015). Returning to the ideas about visual design that we lay out above, it appears that both Hezbollah and IS thus employ a dual sense of the authentic, meeting their audiences' expectations both in terms of production style and the experiential frame of their content.

In deploying these game media to advance discourses of alternate history, however, both IS and Hezbollah prompt further historically-founded questions. Apperley's view above is a reasonable one if we accept that the purpose of games, if not to represent historical truth, is to foster an engagement with history which is in some way educational (the idea of scholarly or didactic purpose is strongly represented in the literature around historical games, e.g. McCall, 2012; Clyde, Hopkins and Wilkinson, 2012; Spring, 2015). Yet as we have demonstrated, the principal use value of these materials is not educational but ideological; and as Arlette Farge suggests, 'it is one thing to understand history as a process of permanent reinterpretation of the past from the standpoint of contemporary society and its needs. It is quite another to press events from the past into the service of ideology' (Farge 1989/2013: 97-8).

\section{Conclusion: ideological games that make historical claims}

Quoting a former US army Chief of Staff, Nieborg (2010) explains that the US does not see the global 'War on Terror' as a war against 'stateless criminals', but as a 'war of ideas': 'This is not simply a fight against terror - terror is a tactic. This is not simply a fight against Al Qaeda, and adherents - they are foot soldiers. This is not simply a fight to bring democracy to the Middle East - that is a strategic objective. This is a fight for the very ideas at the foundation of our society, the ways of life those ideas enable, and the freedoms we enjoy' (Nieborg, 2010: 57).

But in fact, the United States is not alone in this fight for ideas. As we have attempted to show in this article, a number of groups from across the Middle East are challenging Western monopolies over political representation by modifying existing US war games and producing their own.

These videogame interventions, made possible by the democratisation of image production and dissemination during the last few decades, are creating new spaces within which hegemonic and counter-hegemonic narratives are being re-negotiated. In other words, common-sense assumptions on how the world works, on what is good and evil, right and wrong, are no longer unitarily defined by the powerful Western self (Penney, 2010: 190). 'Dissident' narratives have carved their way through mainstream spheres of political identification, through videogames and a range of other visual media productions.

However, in tying this potential for challenging hegemony back to the discourse theoretical approach, we wonder if these interventions simply reproduce the very hegemonic frames they intended to counter (Mouffe, 2005). A significant point in this context is the lack of agency these media products present. While games do have the potential to question determinist and hegemonic interpretations of the past, they cannot do so when the player has no true agency. In fact, several scholars highlight the limitations of 'possibility spaces' within game design; while it may seem that narration in videogames is a free and open process, dependent upon the gamer's skills and decisions, this freedom is an illusion. As demonstrated in the Special Force games, in 
most FPSes, player agency (and thus history) is limited to shooting or not shooting (Reisner, 2013: 252), or perhaps hitting or not hitting, giving some truth to the critique that historical games merely present 'the trappings of history' as a gameplay enhancement or 'masculine backdrop', rather than a form of engagement (Peterson, Miller and Fedorko, 2013: 43; De Groot, 2009: 138). In that sense, players are constantly required to follow a pre-established set of rules, within a prearranged level, with predefined objectives or aims (Intizidis and Prevedourakis, 2008: 212).

Even in the Special Force games, therefore, the player is a witness rather than a participant; there is only one possible version of game play (and one possible version of history): that of the 'resistance' winning over the 'Zionist enemy'. In the IS videos, machinima and advertisements, agency is reduced even further. As such, we embrace Mouffe's (2005) proposition that in its struggle against hegemony, 'resistance' often reproduces similar hegemonic frames, thus contributing to the maintenance and reproduction of the hegemonic order. While these games attempt to produce counter-hegemonic perspectives, the history presented cannot be challenged; by limiting agency, players are no longer actors but acted upon, thus undermining the games' simulation value and pushing them back towards inaccurate, ideological representations of the past.

\section{Notes}

1 Special Force was released in 2002, shortly after the withdrawal of the Israeli army from Southern Lebanon. Special Force 2, produced using an unlicensed copy of Crytek's CryEngine, followed in 2007, only a few months after the July 2006 war between Hezbollah and Israel. We should note that the exact provenance of the video and machinima materials is uncertain, and our attributions are based on the messages conveyed within them. Their support for each organisation is, however, explicit. The ArmA mod itself does not appear to have been made in direct support of IS, although in affording access to playable IS avatars, it creates a context for the production of resistant narratives. Mods of this kind, involving replacement of game graphics and audio files to change the appearance and sounds of in-game characters, are commonly made by players wishing to use such games to represent specific conflicts, or the armed forces of particular nations.

2 Note also that Nick Robinson draws on Paul Virilio's concept of 'pure war' to suggest that 'society is progressively developing into a permanent war economy, where it is increasingly difficult to maintain a clear distinction between periods of war and peace' (Robinson, 202, p. 509).

3 In this context, scholars make an interesting (and quite useful) distinction between the 'real' and the 'realistic' Middle East as depicted in US war games, and between 'realistic' and 'realist' war games more generally: 'for a game producer to suggest that a particular game is realistic is not necessarily problematic. It merely means that the game appears lifelike. To propose that the game is real is problematic as this means that what happens in the game may also happen, or has happened, in reality and that the ideological and political rationale of the game is similar to the world we inhabit with our physical bodies' (Höglund, 2008).

4 Torfing (1999, cited in Carpentier, 2008: 17) distinguishes three domains where discourse theory can be put at work: a) the study of discourses about the media and their place and 
function in society; b) the study of discourses of the mass media (i.e. of the form and content of the discourses produced by the media; c) the study of media as discourse. When applied to the study of Hezbollah and IS videogame productions, this distinction could potentially be very useful: a) the study of mainstream media discourses about the videogames (the alarming narrative most Western media used to cover Hezbollah and IS videogames, considering them as dangerous propaganda and recruitment tools, b) the study of the discourses of the videogames (i.e. the game space they create and the narrative they construct), and c) the study of the videogames as discourses (which is basically what this paper attempts to achieve). 5 Translation by the authors - Tale of the Truthful Pledge: 'The July way... The confrontation that rewrote history ... the battle that drew the beginning of the end of the Zionist entity, and that drew an end to the era of [Arab] defeats, to launch a new era of permanent victories. A realistic reconstitution of the resistance during the July war, which destroyed the myth of "the undefeatable army", and which caused tears to the soldiers who were only used to win. A game developed with the latest 3D technologies, which puts the gamers in the heart of the battle, making him part of the victory by supporting the resistants, and by experiencing what they felt when they destroyed the arsenal of the Zionist enemy and eliminated the aggressors'.

6 In his analysis of the 'persuasive power' of videogames, Bogost (2007) talks about the new spaces for the exploration of rules that games create through processes of experimentation, which he refers to as the 'possibility spaces'. According to Robinson (2012) it is within these spaces of possibility that game modifications (mods) operate. It is also through these spaces that 'games attain their persuasive power and become instrumental to social critique and reflective learning' (Robinson, 2012: 506). But Robinson explains that the potential for successful social protest remains restricted because mods and their 'possibility spaces' are bound to operate within the restrictions of the game's original processes and designs.

\section{References}

Althusser L (2001) Lenin and philosophy and other essays. New York: Monthly Review Press.

Apperley T (2013) Modding the Historians' Code: Historical Verisimilitude and the Counterfactual Imagination. In: Kapell MW and Elliott ABR (eds) Playing with the Past. New York: Bloomsbury Academic, pp.185-98.

Bogost I (2007) Persuasive Games: The Expressive Power of Videogames. Cambridge MA: MIT Press.

Bogost I (2008) The Rhetoric of Video Games. In: Salen K (ed) The Ecology of Games: Connecting Youth, Games, and Learning. Cambridge MA: MIT Press, pp. 117-140.

Bullinger JM and Salvati AJ (2011) A Theory of Brand WW2. Reconstruction: Studies in Contemporary Culture 11(4). Available at: http://reconstruction.eserver.org/Issues/114/SalvatiBullinger.shtml (accessed 26 February 2016). 
Carpentier N (2008) Dichotomized media. Discourses of war. The construction of the self and the enemy in the 2003 Iraq war. In: Carpentier N and Spinoy E (eds) Discourse Theory and Cultural Analysis. New Jersey: Hampton Press, pp. 29-53.

Carpentier N and Cammaerts Bart (2006) Hegemony, democracy, agonism and journalism: an interview with Chantal Mouffe. Journalism studies, 7 (6). Available at http://eprints.lse.ac.uk/3020/1/Hegemony,_democracy,_agonism_and_journalism_(LSERO).pdf (accessed 21 April 2016).

Carr EH (1964) What is History? Harmondsworth: Penguin.

Carter M, Bergstrom K, Webber N and Milik, O (2015) EVE is Real. In: DiGRA '15 -

Proceedings of the 2015 DiGRA International Conference. Available

at: http://www.digra.org/digital-library/publications/eve-is-real/ (accessed 26 February 2016).

Clyde J, Hopkins H and Wilkinson G (2012) Beyond the 'Historical' Simulation: Using Theories of History to Inform Scholarly Game Design. Loading... The Journal of the Canadian Game Studies Association 6(9): 3-16.

De Groot J (2009) Consuming History: Historians and Heritage in Contemporary Culture. London: Routledge.

Der Derian J (2009) Virtuous War: Mapping the Military-Industrial-Media-Entertainment Network, second edition. London: Routledge.

Fairclough N and Wodak R (1997) Critical discourse analysis. In: Van Dick T (ed) Discourse as social interaction: Discourse studies. London: Sage, pp. 258-284.

Farge A (1989/2013) The Allure of the Archives (trans Scott-Railton T). London: Yale University Press.

Frasca G (2003) Simulation versus Narrative. In: Wolf MJP and Perron B (eds) The Video Game Theory Reader. New York: Routledge, pp.221-35.

Galloway A (2004) Social realism in gaming. Game Studies 4(1). Available at http://www.gamestudies.org/0401/galloway/ (accessed on 26 February 2016).

Gish H (2010) Playing the Second World War: Call of Duty and the Telling of History. Eludamos. Journal for Computer Game Culture 4(2), pp.167-80.

Hafez K (2000) Islam and the West in the Mass Media. Fragmented images in a globalizing world. New Jersey: Hampton Press.

Höglund J (2008) Electronic Empire: Orientalism Revisited in the Military Shooter. Game Studies 8(1). Available at http://gamestudies.org/0801/articles/hoeglund (accessed on 26 February 2016). 
Houri W and Saber D (2010) Filming Resistance. A Hezbollah strategy. Radical History Review (106): 70-85.

Huntmann N and Payne MT (2010) Joystick soldiers. The politics of play in military video games. London: Routledge.

Huntmann N (2010) Playing with Fear: Catharsis and Resistance in Military-Themed Video Games. In: Huntmann N and Payne MT (eds) Joystick soldiers. The politics of play in military video games. London: Routledge, pp.223-236.

Intizidis E and Prevedourakis G (2008) An(other) enemy. The representation of otherness in videogame culture. In: Carpentier N and Spinoy E (eds) Discourse Theory and Cultural Analysis. New Jersey: Hampton Press, pp. 209-223.

Jenkins K (2003) Re-thinking History. London: Routledge.

Kapell MW and Elliott ABR (eds) (2013) Playing with the Past. New York: Bloomsbury Academic.

Karim H (2006) American media's coverage of Muslims. The historical roots of comtemporary portrayals. In: Poole E and Richardson J (eds) Muslims and the new media. London: I.B.. Tauris, pp. 116-127.

Laclau E (1977) Politics and ideology in Marxist theory: Capitalism, Fascism, and Populism. London: New Left Books.

Laclau E and Mouffe C (1985) Hegemony and Socialist Strategy. Towards a radical democratic politics. London: Verso.

Laclau E (1988) Metaphor and social antagonisms. In: Nelson C and Grossberg L (eds) Marxism and the interpretation of culture. Urbana: University of Illinois.

Laclau E (1994) The making of political identities. London: Verso.

McCall J (2012) Historical Simulations as Problem Spaces: Criticism and Classroom Use. Journal of Digital Humanities 1(2). Available at: http://journalofdigitalhumanities.org/12/historical-simulations-as-problem-spaces-by-jeremiah-mccall/ (accessed 25 February 2016).

Mouffe C (2005) On the political. London: Routledge.

Nieborg DB (2010) Training Recruits and Conditioning Youth: The Soft Power of Military Games. In: Huntmann N and Payne MT (eds) Joystick soldiers. The politics of play in military video games. London: Routledge, pp.53-66.

Palmer Harik J (2005) Hezbollah: The Changing Face of Terrorism. London: I.B.Tauris. 
Penney J (2010) No Better Way to 'Experience' World War II: Authenticity and Ideology in the Call of Duty and Medal of Honor Player Communities. In: Huntmann N and Payne MT (eds) Joystick soldiers. The politics of play in military video games. London: Routledge, pp.1912016.

Peterson RD, Miller AJ and Fedorko SJ (2013). The Same River Twice: Exploring Historical Representation and the Value of Simulation in the Total

War, Civilization and Patrician Franchises. In: Kapell MW and Elliott ABR (eds) Playing with the Past. New York: Bloomsbury Academic, pp.33-48.

Reisner C (2013) 'The Reality Behind It All Is Very True': Call of Duty: Black Ops and the Remembrance of the Cold War. In: Kapell MW and Elliott ABR (eds) Playing with the Past. New York: Bloomsbury Academic, pp.247-60.

Robinson N (2012) Videogames, Persuasion and the War on Terror: Escaping or Embedding the Military-Entertainment Complex? Political Studies 60(3): 504-522.

Roumani R (2006) Muslims craft their own video games. Christian Science Monitor 5. Available at: http://www.csmonitor.com/2006/0605/p07s02-wome.html (accessed on 27 February 2016).

Said E (1978) Orientalism. New York: Vintage.

Said E (1997) Covering Islam. How the media and the experts determine how we see the rest of the world. New York: Vintage.

Salvati AJ and Bullinger JM (2013) Selective Authenticity and the Playable Past. In: Kapell MW and Elliott ABR (eds) Playing with the Past. New York: Bloomsbury Academic, pp.153-67.

Shaheen J (2000) Hollywood's Muslim Arabs. Muslim World 90(1-2): 22-42.

Šisler V (2008) Digital Arabs: Representation in Video Games. European Journal of Cultural Studies 11(2): 203-220.

Šisler V (2009) Video Games, Video Clips, and Islam: New Media and the Communication of Values. In: Pink J (ed) Muslim Societies in the Age of Mass Consumption. Newcastle: Cambridge Scholars Publishing, pp. 231-258. Available

at: http://www.digitalislam.eu/article.do?articleId=2550 (accessed on 27 February 2016).

Spring D (2015) Gaming history: computer and video games as historical scholarship. Rethinking History: The Journal of Theory and Practice 19(2): 207-21.

Uricchio W (2005) Simulation, History and Computer Games. In Raessens J and Goldstein J (eds) Handbook of Computer Game Studies. Cambridge, Massachusetts: MIT Press, pp.327-38.

White H (1990) The Content of the Form. Baltimore: Johns Hopkins University Press. 